\title{
THE USE OF MOODLE IN TEACHING SPANISH AT THE DEPARTMENT OF IBERIAN STUDIES AT THE FACULTY OF PHILOLOGY IN BELGRADE
}

\author{
Stefan Bondžić \\ University of Belgrade, \\ Faculty of Philology, \\ Čika Ljubina 18-20, Belgrade, Serbia
}

Correspondence:

Stefan Bondžić

e-mail:

bondzic.stefan@gmail.com

\begin{abstract}
:
The constant progress of technology is notable in all spheres of human life, as well as in education. The global expansion of the Internet and computers has changed the approach to learning and teaching. Today, universities and other educational institutions around the world, apart from traditional lectures, offer the possibility of e-learning and distance learning, thereby promoting blended learning. The information and communications technology plays a significant role in education and various studies have confirmed its importance in teaching a second language. Moodle stands out among several virtual learning environments as being most frequently used globally. This e-learning service has found its use at the Faculty of Philology at the University of Belgrade, where it is actively used in teaching Spanish among the students of Spanish, as well as those who learn Spanish as a second language. This paper presents the advantages of ICT in teaching a second language, an increase in the efficiency and motivation among the students attending courses within the virtual learning environment. It also presents how Moodle is used in teaching Spanish, what types of materials are the most attractive and effective for learning.
\end{abstract}

Key words:

moodle in foreign language teaching, blended learning, e-learning materials, motivation.

\section{INTRODUCTION}

The possibilities of new technologies available to humanity in the $21 \mathrm{st}$ century have significantly raised the bar in terms of quality and expectations of the educational process, which includes the teaching of foreign languages. Foreign language teachers have the ability to communicate with their students outside the classroom in the virtual learning environment, with plenty of useful reading materials in accordance with their needs. In this way, the educational process spontaneously starts to take place outside the classroom. On the other hand, learners can count on the constant presence of lecturers and the possibility of online consultations in order to overcome difficulties. Moodle, as a free online global learning platform, has also been used at the Faculty of Philology in Belgrade since the academic year 2010/2011, with over 300 open courses and 7500 registered users.

This paper presents the advantages of using information and communications technology (in further text: ICT) in teaching, their positive 
impact on student motivation and the manner in which Moodle is used in teaching Spanish at the Faculty of Philology. In a poll carried out in June 2015, around 101 students were surveyed, mainly those from the second, third and fourth year of studies at the Department of Iberian Studies, who attend courses of Contemporary Spanish language (G3-G8). Research shows the attitude of the students towards this virtual learning environment, their favorite and/or most efficient types of materials for work, motivation and interest in learning outside the classroom. Special attention is paid to the needs of students, as well as to their evaluation of the attractiveness of the material available in a particular year of study. The results, in addition to a descriptive analysis, may serve as a guide and provide suggestions for future use of Moodle and the improvement of the courses.

\section{THE USE OF ICT IN FOREIGN LANGUAGE TEACHING}

The research has shown that the application of ICT when teaching foreign languages brings benefits to both learners and lecturers. Among the most important areas in which e-learning has an impact on the teaching of foreign languages are developing basic skills, motivation and language learning ability outside the educational institutions (Ristić, 2006: 105). A survey realized by the BECTA (British Education Communications and Technology Agency) highlighted some of the key benefits for students that enable ICT in teaching:

- Digital educational resources allow students individual and personalized work and progress according to their own interests and prior knowledge (Condie \& Munro, 2007: 60).

- Digital educational resources motivate pupils and enable their deeper involvement in the classes, and therefore acquire knowledge more easily (Condie \& Munro, 2007: 66-67).

- In addition, the possibility of learning through experiences that are adopted through video-conferences, and via e-mail, reflects positively on grammar, vocabulary and use of tenses (Ristić, 2006: 105).

- Other important benefits of using ICT in education for teachers of foreign languages:

- Educational attainment is increased via the use of technology, e-learning, since interactive technologies motivate students and teachers.
- Wide choice of resources supports individual needs of the students, whereas multimedia materials (text, visual, sound) give teachers the opportunity to introduce new, interactive and collaborative technologies.

- The possibility of evaluation of each student as well as easy tracking of and individual work and progress with the help of interactive tests with automatic evaluation (Ristić, 2006: 105).

\section{THE IMPACT OF ICT ON MOTIVATION}

ICT already form part of everyday life and therefore are widely used in education, but also in teaching foreign languages (Fitzpatrick \& Davis, 2003).

With the support of ICT in the classroom, language skills are developed faster, whereas they also promote the development of intercultural awareness. Another benefit is easier access to ICT authentic materials, and multimedia materials stimulate progress in learning, as they reach more students. (Klimova \& Poul, 2014: 54). According to the research conducted at the University of Lancaster, the use of ICT in education leads to positive outcomes in the field of motivation, especially when the usage of ICT is oriented towards research and presentation of the previously performed work, as well as when used to support the inclusion of students in the educational process (Passey, Rogers, Machel \& McHugh, 2004: 3). All of the lecturers stressed out that increased motivation was notable among the students, while only individual technical problems, or limited access to the computer and the Internet outside the school, were a negative factor when making assignments and using the information and communication technologies. (Passey et al, 2004: 33)

The European Commission report on the use of new technologies and the Internet in teaching of foreign languages within the ImpaCT2 study, points out that students at schools that have used ICT in teaching recorded better results, and that a significant positive correlation between the use of ICT in teaching language and score on the final examination (Fitzpatrick \& Davis, 2003) could be observed. ICT in teaching encourage student motivation, facilitate course management and provide access to attractive material for processing various teaching units. They are also useful because they provide the opportunity to learn outside the classroom- students can work independently at home (Passey et al, 2004: 62). 


\section{MOODLE AS A VIRTUAL LEARNING ENVIRONMENT}

Moodle is free, highly flexible software for e-learning, ("Home." Thefreedictionary.com) distance learning or blended learning. ("About Moodle. 'Moodle.org), and is also course management system, i.e. virtual learning environment; its title comes from the abbreviations for Modular Objected Oriented Dynamic Learning Environment - Moodle ("Home." Thefreedictionary.com).

The creator of the Moodle is Martin Dougiamas, whose aim was to provide a platform for online courses that would encourage a collaborative approach to building and content selection for teaching. The first version was launched on the 20th of August, 2002 and ever since a constant effort has been made to improve this virtual environment and its function ("History." Moodle.org).

The advantage of Moodle is its practical use and easy access: users (lecturers and learners) need just a username and a password to access this virtual environment for learning.. Taking into account that this is an online platform, users can access anytime, anywhere, from any computer that has Internet connection. Therefore, it is considered an excellent system that allows users the autonomy in learning, and encourages a collaborative approach to the learning process among the students (Warth-Sontheimer, 2011:4).

Moodle is an open system when it comes to the material selection and course organisation. As a virtual learning environment, it does not offer predetermined materials, but allows lecturers to choose, create and download the material from the Internet or other sources.

Today, Moodle has a customer base that includes 56,831 registered sites with $75,895,336$ users, divided into 8,396,861 courses, in 221 countries ("Moodle Statistics." moodle.org).

Moodle platform can be downloaded for free from the official website of the association and is compatible with all major operating systems such as Windows, Linux, Mac OS, Unix, and all systems that support PHP database.("Installing Moodle. 'Moodle.org) With the rapid development of technology, Moodle can be accessed via mobile phones running the operating system Android, iOS, or Windows Phone ("Mobile Home". Moodle.org).

\section{MOODLE AND BLENDED LEARNING}

Moodle, as a virtual learning environment, has got multiple applications in the classroom: it can be used for distance learning, but also supports the standard, traditional model of teaching and blended learning. This environment gives complete flexibility when choosing the materials and organizing lessons so that each course can be fully adapted to the needs of the students.

Blended learning involves the type of learning in which the student gets the knowledge inside the educational institution, by the traditional form of teaching, while the other part is realized by means of electronic services (Staker \& Horn, 2012: 3). Traditionally, this type of learning is described as a combination of teaching and learning through Internet and digital media with the usual manner of teaching in the classroom, which includes the physical presence of students and lecturers (Friesen, 2012: 1). On the other hand, some authors define this process as the union of different teaching modalities combined with synchronous and/or asynchronous web technologies that facilitate interactive, reflective and collective learning (Lupshenyuk \& Adams, 2009: 717). Still, some describe it as a hybrid process that is based on traditional teaching methods (face to face) and internet learning that takes place both in the classroom and outside - online, where learning through the Internet and digital media becomes a natural extension of the traditional learning process (Liebowitz \& Frank, 2011 by Al-Ani1, 2013: 99).

Many studies have shown that the use of Moodle in the classroom encourages learning outside the classroom, and that is undoubtedly useful both to the lecturers and students (Al-Ani1, 2013: 9 of 9). In addition, the usage of Modle as a learning management system, which is based on socio-constructivist learning model (Melton, 2008 by Al-Anil, 2013: 99) provides access to learning aimed at the students and encourages the lecturers and students to active work in the educational institution at home, contributing at the same time to development of constructive learning (Govender, 2009 by Al-Anil, 2013: 99).

According to these sources, it is obvious that the use of the virtual learning environment is one of the most beneficial aspects of restructuring strategies in learning, since it is intended for students, giving them the ability of an intensive immersion in the learning process (AlAni1, 2013: 100). In addition, when it comes to higher education, it has been noted that with the use of Moodle the number of students who drop out has reduced, while there has been a significant improvement of the average notes (Lopez-Perez, V., Perez-Lopez, C., \& RodriguezAriza, 2011 by Al-Ani1, 2013: 100). 


\section{MOODLE IN EDUCATION}

From the pedagogical point of view, Moodle supports the socio-constructivist approach to education, encouraging students and teachers to contribute to the educational process (Brand, 2005: 20). With the help of these pedagogical principles, Moodle provides a flexible learning environment. Also, another important factor in blended learning is the ability of a lecturer to properly conduct a thoroughly planned and organized syllabus of the subject. This refers to the combination of classroom activities and those realized online by students outside the classroom (Krasnova \& Sidorenko, 2013).

Numerous studies confirm the increased motivation among the learners, as well as the higher efficiency during the learning process when Moodle is used, compared to the traditional model of teaching, according to the research conducted at the University of Tallinn (Siirak, 2012: 95).

Students showed a higher level of interest and motivation for the courses that have used Moodle as a learning support, and confirmed that they achieve better personal contacts, as well as being successful in the learning process, while progressing faster and simultaneously learning from each other (Siirak, 2012: 95).

\section{THE USE OF MOODLE AT THE}

\section{DEPARTMENT OF IBERIAN STUDIES AT THE FACULTY OF PHILOLOGY IN BELGRADE}

Moodle, as a virtual learning environment, is being used at the Department of Iberian Studies, Faculty of Philology in Belgrade, since the 20011/12 academic year. Today there are over 300 courses and 75000 registered users. Moodle has also found its use in the teaching of the Spanish language, since subjects such Contemporary Spanish Language in all four years of study (G1-G8) count on the support of the virtual courses within the Moodle platform.

This paper examines whether the students find Moodle to be a useful mean of support in the learning process. Also, it will investigate the matter of the blended learning method with the support of Moodle, as well as the type of material the students feel most comfortable to work with, and which type of content is considered to be the most effective for developing language competences.

In June 2015, the students of the second, third and fourth year of the study program Spanish, Hispanic Lit- erature and Culture were surveyed (101 students) in order to investigate their views and thoughts on the use of Moodle platform in the subjects Contemporary Spanish Language (G3-G8).

\section{DESCRIPTIVE STATISTICS ON A SAMPLE OF RESPONDENTS WHO ATTEND MOODLE COURSES CONTEMPORARY SPANISH LANGUAGE G3-G8}

In general, text files in all three years of study have not been labelled as particularly attractive, nor inefficient. However, the respondents who did not indicate their year of the study labeled the text documents somehow more attractive - the average of their responses is $2.75 .{ }^{1}$ Taking into account all of the answers, the average score of attractiveness of the text documents is 3.02 (Table 1).

When it comes to the attractiveness of audio files, average values are slightly lower when compared to text files. Second-year students gave the audio files the lowest rating (3.43), while the third-year students compared with an on average record, labelled them better (3.10). On the overall, an average note of 3.21 indicates that audio files are not highly attractive, but still not repulsive to the students (Table 2).

Video records were the least attractive to the students who did not mark their year of study (3.33), as well as to the students of the second year (3.29). This type of content was more interesting to the students of the third (2.93) and the fourth year (2.74). Generally, videos are were more attractive than the first two types of content, and it is evident that the average rating is growing according to the level of study. Therefore, we can conclude that proficient students prefer to work with multimedia material such as video recordings, since they have a higher level of language competence, while other students are still not at that level. Overall ratings of the video materials is slightly above average, 2.93 (Table 3).

Presentations are, in general, estimated as slightly more attractive type of material than the video files (2.85). Second-year students find this type of content as highly attractive (2.07), while the third-year students labelled presentations as least attractive- 3.14 (Table 4).

Graphic materials, also, were not labelled as particularly attractive nor as very unattractive content (2.95). Fourth-year students (3.11) and students who did not indicate their year of studies (3.13) have estimated this

1 Note: rank 1- the most attracitve, rank 5- the least attractive 


\begin{tabular}{|c|c|c|c|c|c|c|c|}
\hline \multirow{2}{*}{\multicolumn{2}{|c|}{ Year of study }} & \multicolumn{6}{|c|}{ What content is the most attractive to you (Text files) } \\
\hline & & \multirow{2}{*}{$\begin{array}{c}\text { Rank } 1 \\
3\end{array}$} & \multirow{2}{*}{$\begin{array}{c}\text { Rank } 2 \\
4\end{array}$} & \multirow{2}{*}{$\begin{array}{c}\text { Rank } 3 \\
1\end{array}$} & \multirow{2}{*}{$\begin{array}{c}\text { Rank } 4 \\
2\end{array}$} & \multirow{2}{*}{$\begin{array}{c}\text { Rank } 5 \\
4\end{array}$} & \multirow{3}{*}{$\frac{M}{3.00}$} \\
\hline \multirow{2}{*}{ Second } & Number & & & & & & \\
\hline & Percentage & 21.4 & 28.6 & 7.1 & 14.3 & 28.6 & \\
\hline \multirow{2}{*}{ Third } & Number & 9 & 2 & 5 & 3 & 10 & \multirow{2}{*}{3.10} \\
\hline & Percentage & 31.0 & 6.9 & 17.2 & 10.3 & 34.5 & \\
\hline \multirow{2}{*}{ Fourth } & Number & 13 & 8 & 4 & 9 & 13 & \multirow{2}{*}{3.02} \\
\hline & Percentage & 27.7 & 17.0 & 8.5 & 19.1 & 27.7 & \\
\hline \multirow{2}{*}{ Unlabelled } & Number & 4 & 0 & 1 & 0 & 3 & \multirow{2}{*}{2.75} \\
\hline & Percentage & 50.0 & 0 & 12.5 & 0.0 & 37.5 & \\
\hline \multirow{2}{*}{ In total } & Number & 29 & 14 & 11 & 14 & 30 & \multirow{2}{*}{3.02} \\
\hline & Percentage & 29.6 & 14.3 & 11.2 & 14.3 & 30.6 & \\
\hline
\end{tabular}

Table 1. Distribution of text files as the most attractive content per academic year

\begin{tabular}{|c|c|c|c|c|c|c|c|}
\hline \multirow{2}{*}{\multicolumn{2}{|c|}{ Year of study }} & \multicolumn{6}{|c|}{ What content is most attractive to you (Audio files) } \\
\hline & & Rank 1 & Rank 2 & Rank 3 & Rank 4 & Rank 5 & M \\
\hline \multirow{2}{*}{ Second } & Number & 3 & 0 & 2 & 6 & 3 & \multirow{2}{*}{3.43} \\
\hline & Percentage & 21.4 & 0.0 & 14.3 & 42.9 & 21.4 & \\
\hline \multirow{2}{*}{ Third } & Number & 2 & 7 & 10 & 6 & 4 & \multirow{2}{*}{3.10} \\
\hline & Percentage & 6.9 & 24.1 & 34.5 & 20.7 & 13.8 & \\
\hline \multirow{2}{*}{ Fourth } & Number & 4 & 7 & 18 & 11 & 7 & \multirow{2}{*}{3.21} \\
\hline & Percentage & 8.5 & 14.9 & 38.3 & 234 & 14.9 & \\
\hline \multirow{2}{*}{ Unlabelled } & Number & 1 & 2 & 1 & 2 & 2 & \multirow{2}{*}{3.25} \\
\hline & Percentage & 12.5 & 25.0 & 12.5 & 25.0 & 25.0 & \\
\hline \multirow{2}{*}{ In total } & Number & 10 & 16 & 31 & 25 & 16 & \multirow{2}{*}{3.21} \\
\hline & Percentage & 10.2 & 16.3 & 31.6 & 25.5 & 16.3 & \\
\hline
\end{tabular}

Table 2. Distribution of audio files as the most attractive content per academic year

\begin{tabular}{|c|c|c|c|c|c|c|c|}
\hline \multirow{2}{*}{\multicolumn{2}{|c|}{ Year of study }} & \multicolumn{6}{|c|}{ What content is most attractive to you (Video files) } \\
\hline & & Rank 1 & Rank 2 & Rank 3 & Rank 4 & Rank 5 & $\mathrm{M}$ \\
\hline \multirow{2}{*}{ Second } & Number & 2 & 3 & 2 & 3 & 4 & \multirow{2}{*}{3.29} \\
\hline & Percentage & 14.3 & 21.4 & 14.3 & 21.4 & 28.6 & \\
\hline \multirow{2}{*}{ Third } & Number & 8 & 5 & 3 & 7 & 6 & \multirow{2}{*}{2.93} \\
\hline & Percentage & 27.6 & 17.2 & 10.3 & 24.1 & 20.7 & \\
\hline \multirow{2}{*}{ Fourth } & Number & 10 & 12 & 12 & 6 & 7 & \multirow{2}{*}{2.74} \\
\hline & Percentage & 21.3 & 25.5 & 25.5 & 12.8 & 14.9 & \\
\hline \multirow{2}{*}{ Unlabelled } & Number & 2 & 1 & 1 & 2 & 3 & \multirow{2}{*}{3.33} \\
\hline & Percentage & 22.2 & 11.1 & 11.1 & 22.2 & 33.3 & \\
\hline \multirow{2}{*}{ In total } & Number & 22 & 21 & 18 & 18 & 20 & \multirow{2}{*}{2.93} \\
\hline & Percentage & 22.2 & 21.2 & 18.2 & 18.2 & 20.2 & \\
\hline
\end{tabular}

Table 3. Distribution of video files as the most attractive content per academic year

\begin{tabular}{|c|c|c|c|c|c|c|c|}
\hline \multirow{2}{*}{\multicolumn{2}{|c|}{ Year of study }} & \multicolumn{6}{|c|}{ What content is most attractive to you (Presentations) } \\
\hline & & \multirow{2}{*}{$\begin{array}{c}\text { Rank } 1 \\
4\end{array}$} & \multirow{2}{*}{$\begin{array}{c}\text { Rank } 2 \\
7\end{array}$} & \multirow{3}{*}{$\begin{array}{c}\text { Rank 3 } \\
2 \\
143\end{array}$} & \multirow{3}{*}{$\begin{array}{c}\text { Rank } 4 \\
0 \\
0.0\end{array}$} & \multirow{3}{*}{$\begin{array}{c}\text { Rank } 5 \\
1 \\
7.1\end{array}$} & \multirow{3}{*}{$\begin{array}{c}\mathrm{M} \\
2.07\end{array}$} \\
\hline \multirow{2}{*}{ Second } & Number & & & & & & \\
\hline & Percentage & 28.6 & 50.0 & & & & \\
\hline \multirow{2}{*}{ Third } & Number & 2 & 8 & 6 & 10 & 3 & \multirow{2}{*}{3.14} \\
\hline & Percentage & 6.9 & 27.6 & 20.7 & 34.5 & 10.3 & \\
\hline \multirow{2}{*}{ Fourth } & Number & 10 & 11 & 6 & 13 & 7 & \multirow{2}{*}{2.91} \\
\hline & Percentage & 21.3 & 234 & 12.8 & 27.7 & 14.9 & \\
\hline \multirow{2}{*}{ Unlabelled } & Number & 0 & 4 & 2 & 2 & 0 & \multirow{2}{*}{2.75} \\
\hline & Percentage & 0 & 50.0 & 25.0 & 25.0 & 0 & \\
\hline \multirow{2}{*}{ In total } & Number & 16 & 30 & 16 & 25 & 11 & \multirow{2}{*}{2.85} \\
\hline & Percentage & 16.3 & 30.6 & 16.3 & 25.5 & 11.2 & \\
\hline
\end{tabular}

Table 4. Distribution of presentations as the most attractive content per academic year 
type of content slightly less interesting the second-year (2.79) and third-year students (2.72), who found it more appealing (Table 5).

All second-year students stated that they receive their favorite type of content from the lecturers often enough, which is also the case with the $89 \%$ of the students who did not mark their year of study. However, $53 \%$ of the third-year, and $23 \%$ of the fourth-year students, states that they do not receive their most attractive type of material often enough. On the overall, $28 \%$ of respondents believe that the lecturers do not upload their favorite type of material often enough (Table 6).

The respondents reported that they were mostly influenced by the materials which led them to listening to a song or a music album (50\%) seeing a movie (46\%) and reading some articles (44\%). About $17 \%$ of the respondents said that a specific content influenced them to read a book, while $12 \%$ of the students remarked that they were encouraged by some of the material from Moodle to visit a photography exhibition or some other visual works. Second-year students show that it was music which had the strongest impact (71\%), as well as among the thirdyear students (56\%). On the other hand, respondents from the fourth year of study pointed out that they were mostly influenced to see a movie (49\%), which is in line with their abovementioned answer about the most attractive type of material- video. It is highly positive and encouraging that only $12 \%$ of the students said that none of the materials affected them in any way (Table 7).

The students were mostly affected by text files - $48 \%$ marked them, as well as video recordings - $45 \%$ of respondents reported that this type of material influenced them to see or search for different content. The respondents were least interested in graphic materials (15\%), presentations (19\%) and audio files (25\%). When it comes to the second-year students, most of them were affected by text files (71\%), which also have a distinguished overall rating among the third-year students, who equally labelled text and video files (47\%). Once again, there is a significant increase in the average rating of video files, according to the year of study: $21 \%$ of the second and $47 \%$ of the third-year students have marked this kind of material as well as $51 \%$ of the fourth-year respondents marked video files as a type which had most influence on them and encouraged them to continue with academic activities outside the classroom (Table 8).

This table shows types of materials that influenced students, but taking into account only the respondents who labelled a certain type of material with the highest rating (1- most attractive). About $55 \%$ of the respondents who marked text documents as the most attractive material pointed out that it was precisely this type of material that influenced them most to view certain content. Among the students who labelled audio files as the most attractive material, the highest percentage of respondents, $40 \%$, marked text, audio and video files as a material that had most influence on them. About $82 \%$ of the respondents who labelled video files as the most attractive material pointed out that it was precisely this type of material that influenced them most to view certain content. In addition, the highest percentage of respondents who consider presentations as the most attractive type of material, pointed out that text files had most influence on them (50\%); the situation was similar with the students who labelled graphic materials as the most attractive type of material- 55\% (Table 9).

Second-year students considered text documents to be the most effective materials for progress in learning the Spanish language - $86 \%$ of the respondents marked this option. Third-year students also labelled text and video files: $47 \%$ of the respondents selected these two types of materials as the most effective. Fourth-year students point out video files as the most effective type of materials (64\%), followed by text files and presentations (40\%). When looking at the overall results, the lowest percentage of the students marked graphic files as the most effective material for the learning process (12\%), followed by audio files (29\%), while the most effective material for learning are videos (51\%) and text files (48\%). There is a notable decline in the preference for text files as the year of study is growing: $86 \%$ first-year students marked this type of material as the most effective content for learning, but this percentage decreased among the respondents in the third (47\%) and the fourth-year of study (40\%). On the other hand, the average rating of video files grew with the year of study: $21 \%$ of the respondents from the second year, $44 \%$ of the third and $51 \%$ students from the fourth year of study marked this type of material as the most effective. Such dynamics of increasing average grade was observed with audio-record: $14 \%, 28 \%$ and $34 \%$ of the second, third and fourth year of study (Table 10).

At this point the respondents' answers about which materials their lecturers upload frequently can be linked to the answers about the most efficient materials for an advance in the learning process of the Spanish language. So, it is notable that about a half of the respondents labelled text files (48\%) and videos (51\%) as the most efficient. However, although the respondents stated that teachers often upload text documents to Moodle (1.87), this is not the case with video files (3.32). Therefore, it might be 


\begin{tabular}{|c|c|c|c|c|c|c|c|}
\hline \multirow{2}{*}{\multicolumn{2}{|c|}{ Year of study }} & \multicolumn{5}{|c|}{ What content is most attractive to you (Graphic material) } & \multirow{4}{*}{$\begin{array}{c}\mathrm{M} \\
2.79\end{array}$} \\
\hline & & \multirow{2}{*}{$\frac{\text { Rank } 1}{3}$} & \multirow{2}{*}{$\frac{\text { Rank } 2}{1}$} & \multirow{2}{*}{$\begin{array}{c}\text { Rank } 3 \\
7\end{array}$} & \multirow{2}{*}{$\frac{\text { Rank } 4}{2}$} & \multirow{3}{*}{$\begin{array}{c}\text { Rank } 5 \\
1 \\
7.1\end{array}$} & \\
\hline \multirow{2}{*}{ Second } & Number & & & & & & \\
\hline & Percentage & 21.4 & 7.1 & 50.0 & 14.3 & & \\
\hline \multirow{2}{*}{ Third } & Number & 8 & 7 & 5 & 3 & 6 & \multirow{2}{*}{2.72} \\
\hline & Percentage & 27.6 & 24.1 & 17.2 & 10.3 & 20.7 & \\
\hline \multirow{2}{*}{ Fourth } & Number & 10 & 9 & 7 & 8 & 13 & \multirow{2}{*}{3.11} \\
\hline & Percentage & 21.3 & 19.1 & 14.9 & 17.0 & 27.7 & \\
\hline \multirow{2}{*}{ Unlabelled } & Number & 1 & 1 & 3 & 2 & 1 & \multirow{2}{*}{3.13} \\
\hline & Percentage & 12.5 & 12.5 & 37.5 & 25.0 & 12.5 & \\
\hline \multirow{2}{*}{ In total } & Number & 22 & 18 & 22 & 15 & 21 & \multirow{2}{*}{2.95} \\
\hline & Percentage & 22.4 & 18.4 & 22.4 & 15.3 & 21.4 & \\
\hline
\end{tabular}

Table 5. Distribution of graphic files as the most attractive content per academic year

\begin{tabular}{cccc}
\hline \multirow{2}{*}{ Year of study } & Do you think your teacher sends you the most attractive type of material often enough \\
\cline { 2 - 4 } & & Yes & No \\
\hline \multirow{2}{*}{ Second } & Number & 14 & 0 \\
\cline { 2 - 4 } & Percentage & 100.0 & 0.0 \\
\hline \multirow{2}{*}{ Third } & Number & 15 & 17 \\
\cline { 2 - 4 } & Percentage & 46.9 & 53.1 \\
\hline \multirow{2}{*}{ Fourth } & Number & 36 & 11 \\
\cline { 2 - 4 } & Percentage & 76.6 & 134 \\
\hline \multirow{2}{*}{ Unlabelled } & Number & 8 & 11.1 \\
\cline { 2 - 4 } & Percentage & 88.9 & 29.4 \\
\hline \multirow{2}{*}{ In total } & Number & 73 & Percentage
\end{tabular}

Table 6. Material upload frequency per academic year

\begin{tabular}{cccccccc}
\hline \multirow{2}{*}{ Year of study } & \multicolumn{5}{c}{ Did any of these materials influence you to see / listen to / read } \\
\cline { 2 - 8 } & Movie & Music & Book & Article & Photo & None \\
\hline \multirow{2}{*}{ Second } & Number & 5 & 10 & 5 & 8 & 1 & 0 \\
\cline { 2 - 8 } & Percentage & 35.7 & 71.4 & 35.7 & 57.1 & 7.1 & 0.0 \\
\hline \multirow{2}{*}{ Third } & Number & 17 & 18 & 3 & 12 & 7 & 4 \\
\cline { 2 - 8 } & Percentage & 53.1 & 56.3 & 9.4 & 37.5 & 21.9 & 12.5 \\
\hline \multirow{2}{*}{ Fourth } & Number & 23 & 19 & 7 & 22 & 4 & 7 \\
\cline { 2 - 8 } & Percentage & 48.9 & 40.4 & 14.9 & 46.8 & 8.5 & 14.9 \\
\hline \multirow{2}{*}{ Unlabelled } & Number & 2 & 4 & 2 & 3 & 0 & 1 \\
\cline { 2 - 8 } & Percentage & 22.2 & 44.4 & 22.2 & 33.3 & 0.0 & 11.1 \\
\hline \multirow{2}{*}{ In total } & Number & 47 & 51 & 17 & 45 & 12 & 12 \\
\cline { 2 - 7 } & Percentage & 46.1 & 50.0 & 16.7 & 44.1 & 11.8 & 11.8 \\
\hline
\end{tabular}

Table 7. Distribution of the impact that different types of materials have on students

\begin{tabular}{|c|c|c|c|c|c|c|}
\hline \multirow{2}{*}{\multicolumn{2}{|c|}{ Year of study }} & \multicolumn{5}{|c|}{ What type of material has influenced you } \\
\hline & & \multirow{2}{*}{$\begin{array}{c}\text { Text files } \\
10\end{array}$} & \multirow{2}{*}{$\frac{\text { Audio files }}{4}$} & \multirow{2}{*}{$\frac{\text { Video files }}{3}$} & \multirow{2}{*}{$\begin{array}{c}\text { Presentations } \\
3\end{array}$} & \multirow{2}{*}{$\frac{\text { Graphic files }}{4}$} \\
\hline Sorond & Number & & & & & \\
\hline second & Percentage & 71.4 & 28.6 & 21.4 & 21.4 & 28.6 \\
\hline \multirow{2}{*}{ Third } & Number & 15 & 9 & 15 & 9 & 8 \\
\hline & Percentage & 46.9 & 28.1 & 46.9 & 28.1 & 25.0 \\
\hline \multirow{2}{*}{ Fourth } & Number & 21 & 9 & 24 & 7 & 3 \\
\hline & Percentage & 44.7 & 19.1 & 51.1 & 14.9 & 6.4 \\
\hline \multirow{2}{*}{ Unlabelled } & Number & 3 & 3 & 4 & 0 & 0 \\
\hline & Percentage & 33.3 & 33.3 & 44.4 & 0.0 & 0.0 \\
\hline \multirow{2}{*}{ In total } & Number & 49 & 25 & 46 & 19 & 15 \\
\hline & Percentage & 48.0 & 24.5 & 45.1 & 18.6 & 14.7 \\
\hline
\end{tabular}

Table 8. Distribution of the type of material per year of study which has encouraged students to work independently 


\begin{tabular}{|c|c|c|c|c|c|c|}
\hline \multirow{2}{*}{\multicolumn{2}{|c|}{$\begin{array}{l}\text { Type of material which was } \\
\text { designated as the most at- } \\
\text { tractive }\end{array}$}} & \multicolumn{5}{|c|}{ What type of material influenced you to browse certain content } \\
\hline & & \multirow{2}{*}{$\begin{array}{c}\text { Text files } \\
16 \\
\end{array}$} & \multirow{2}{*}{$\begin{array}{c}\text { Audio files } \\
6\end{array}$} & \multirow{2}{*}{$\begin{array}{c}\text { Video files } \\
9\end{array}$} & \multirow{2}{*}{$\begin{array}{c}\text { Presentations } \\
66\end{array}$} & \multirow{2}{*}{$\begin{array}{c}\text { Graphic files } \\
1\end{array}$} \\
\hline Teyt files & Number & & & & & \\
\hline Iext nies & Percentage & 55.2 & 20.7 & 31.0 & 20.7 & 3.4 \\
\hline \multirow{2}{*}{ Audio files } & Number & 4 & 4 & 4 & 2 & 3 \\
\hline & Percentage & 40.0 & 40.0 & 40.0 & 20.0 & 30.0 \\
\hline \multirow{2}{*}{ Video files } & Number & 6 & 5 & 18 & 0 & 4 \\
\hline & Percentage & 27.3 & 22.7 & 81.8 & 0.0 & 18.2 \\
\hline \multirow{2}{*}{ Presentations - } & Number & 8 & 4 & 5 & 4 & 2 \\
\hline & Percentage & 50.0 & 25.0 & 31.3 & 25.0 & 12.5 \\
\hline \multirow{2}{*}{ Graphic files - } & Number & 12 & 7 & 10 & 5 & 5 \\
\hline & Percentage & 54.5 & 31.8 & 45.5 & 22.7 & 22.7 \\
\hline
\end{tabular}

Table 9. The most attractive materials and their impact on students

\begin{tabular}{|c|c|c|c|c|c|c|}
\hline \multirow{2}{*}{\multicolumn{2}{|c|}{ Year of study }} & \multicolumn{5}{|c|}{$\begin{array}{l}\text { What content and materials on Moodle you consider to be the most effective for progress in } \\
\text { learning the Spanish language }\end{array}$} \\
\hline & & Text files & Audio files & Video files & Presentations & Graphic files \\
\hline \multirow{2}{*}{ Second } & Number & 12 & 2 & 3 & 4 & 1 \\
\hline & Percentage & 85.7 & 14.3 & 21.4 & 28.6 & 7.1 \\
\hline \multirow{2}{*}{ Third } & Number & 15 & 9 & 15 & 13 & 6 \\
\hline & Percentage & 46.9 & 28.1 & 46.9 & 40.6 & 18.8 \\
\hline \multirow{2}{*}{ Fourth } & Number & 19 & 16 & 30 & 19 & 4 \\
\hline & Percentage & 40.4 & 34.0 & 63.8 & 40.4 & 8.5 \\
\hline \multirow{2}{*}{ Unlabelled } & Number & 3 & 3 & 4 & 2 & 1 \\
\hline & Percentage & 33.3 & 33.3 & 44.4 & 22.2 & 11.1 \\
\hline \multirow{2}{*}{ In total } & Number & 49 & 30 & 52 & 38 & 12 \\
\hline & Percentage & 48.0 & 29.4 & 51.0 & 37.3 & 11.8 \\
\hline
\end{tabular}

Table 10. Ranking of the most effective learning materials by year of study

necessary to increase the amount of videos being uploaded to Moodle, since the respondents believe that this type of content is very effective for learning process, especially among the third and fourth-year students. When it comes to graphic files, the respondents reported that these are the least frequent type of material on Moodle (3.42), but they also feel that they are the least useful for the learning process- only $12 \%$ of the respondents chose them as the most effective.

\section{OBJECTIONS AND SUGGESTIONS}

As the biggest objection students indicated that the system stops working if there are many people connected. This usually happens when they sign up term papers or during tests. Half of the respondents pointed out this problem. A small number of students also highlights an inadequate use of the platform by the lecturers, poor organization, errors in automatic evaluation of certain tests, etc.
Learners suggested uploading more diverse materials, and their participation in the diffusion of materials, as well as better organization. Respondents especially emphasized that they would like more audio and video materials.

\section{CONCLUSION}

This paper describes the benefits of using ICT in teaching, its positive impact on the student motivation and progress, of the students, with the main features of Moodle as a virtual environment that facilitates blended learning. On this occasion, in order to gain an insight into the use of Moodle in the teaching of the Spanish language at the Faculty of Philology in Belgrade, 100 students have been surveyed. Although the study is limited since there is no test group to compare the results with, highly positive responses of the learners cannot be disputed.

The results show that the learners' favorite and/or most efficient type of material to work with, as well as 
increased motivation and interest in learning outside the classroom. The general impression is very positive and the students have particularly pointed out the possibility of consulting with their colleagues and easy access to materials at one place, as well as faster access to the information concerning the course and materials.

When it comes to the upload frequency of the most attractive materials on Moodle, it is noticeable among the students of Spanish, that they believe their lecturers do not deliver their favorite type of material quite often enough. Therefore, it may be a good idea to post videos and presentations more frequently. Of course, it is necessary to bear in mind the needs and level of knowledge of each year of study. For instance, the average rating of a video as a favorite material to work increases from the second to the fourth year of study along with the increase of language competencies, while the average score of text files is decreases. .

The results showing the impact of Moodle to students' activities outside the classroom are encouraging: as much as $88 \%$ of the surveyed students of Spanish indicated that they were inspired by some of the online content, read a book, an article, watched a movie in Spanish, etc. When it comes to the role of Moodle in blended learning, it is obvious that it has not entirely achieved its potential, since the majority of surveyed students (85\%) said that they weekly spend one hour maximum with this learning platform. However, in the long run, and this percentage could probably improve, should the lecturers pay particular attention to the expressed needs and preferences of the student with enough online material for practice.

Since it came into use in the school year 2010/2011 at the Faculty of Philology, Moodle has consolidated itself as an important platform for the exchange of information, following the material and syllabus, which provides a fundamental possibility of electronic learning. It allows communication, both between the teachers and students, and promotes socialization, getting to know each other and dealing with the formal barriers between the students and teaching staff, which is especially important when it comes to learning foreign languages. The general opinion of the students on the Moodle platform is highly positive, though there is still much space for further progress. Namely, it is necessary to pay attention to students' suggestions and criticisms concerning the course organisation, the lack of material for exercise in order to take advantage of the opportunities that this virtual learning environment offers, and ensure optimal outcomes.

\section{REFERENCES}

Al-Anil, Wajeha Thabit. "Blended Learning Approach Using Moodle and Student's Achievement at Sultan Qaboos University in Oman." Journal of Education and Learning, 2(3), Canadian Center of Science and Education, 2013.

Brandl, Klaus. "Are you ready to moodle." Language Learning \& Technology, 9(2), 2005: 16-23. Retrieved July 7, 2015, from http://ltt.msu.edu/vol9num2/pdf/review1.pdf

Condie, Rae and Bob Munro. The impact of ICT in schools: Landscape review. British Educational Communications and Technology Agency (BECTA), 2007. Retrieved August 15, 2015, from http:// citeseerx.ist.psu.edu/viewdoc/download;jsessionid= CC120CB92555C36FCD2F51A6B4703417?doi=10. 1.1.170.6394\&rep $=$ rep $1 \&$ type $=$ pdf

Fitzpatrick, Tony and Graham Davis. European Comission Report: The impact of ICT on the teaching of foreign languages and on the role of teachers of foreign languages. 2003. Retrieved July 20, 2015, from http://www.camsoftpartners.co.uk/docs/ICC_Grahams_Report_Final.htm

Friesen, Norm. Report: Defining Blended Learning. 2012. Retrieved July 15, 2015, from http://learningspaces. org/papers/Defining_Blended_Learning_NF.pdf

Frydrychova Klimova, Blanka and Petra Poulova. "ICT as a motivational tool in the learning of foreign languages." The 2014 International Conference on Education and Modern Educational Technologies. Santorini, 2014: 53-56. Retrieved June 15, 2015, from http://www.europment.org/library/2014/interlaken/bypaper/EDU/EDU-06.pdf

Govender, Irene. "The learning context: Influence on learning to program." Computers \& Education, 53(4), 2009: 1218-1230.

Krasnova, Tatiana \& Tatiana Sidorenko. "Blended Learning in Teaching Foreign Languages." The 6th Edition of the International Conference ICT for Language Learning, Florence, 2013. Retrieved June 15, 2015, from http://conference.pixel-online.net/ ICT4LL2013/common/download/Paper_pdf/113ELE08-FP-Sidorenko-ICT2013.pdf

Liebowitz, Jay, \& Micheal Frank. Knowledge Management and E-learning. Auerbach Publications, Taylor \& Francis Group: USA, 2011.

Lopez-Perez, Maria V., M. Carmen Perez-Lopez \& Lazaro Rodriguez-Ariza. "Blended learning in higher education: Students' perceptions and their relation to outcomes."Computers \& Education, 56(3), 818-826. 
Lupshenyuk, Denys \& Jean Adams. "Workplace Learners' Perceptions towards a Blended Learning Approach." World Academy of Science, Engineering and Technology, Vol. 3, 2009: 717-721. Retrieved May 15, 2015, from http://waset.org/publications/10645/workplace-learners-perceptions-towards-a-blended-learning-approach

Melton, Jay. "Need an LMS? Try the Open Source Package Moodle." Journal of Instruction Delivery Systems, 22(1), 2008: 18-21.

Moodle.com:

"History" Retrieved August 15, 2015, from https://docs. moodle.org/29/en/History

"About Moodle" Retrieved August 15, 2015, from https:// docs.moodle.org/29/en/About_Moodle

"Installing Moodle" Retrieved August 15, 2015, from https://docs.moodle.org/29/en/Installing_Moodle

"Moodle Mobile" Retrieved August 15, 2015, from https://docs.moodle.org/28/en/Moodle_Mobile

"Moodle Statistics" Retrieved August 15, 2015, from https://docs.moodle.org/22/en/Statistics

Passey, Don, Colin Rogers, Joan Machell \& Gilly McHugh. The Motivational Effect of ICT on Pupils. Department of Educational Research Lancaster University, 2004. Retrieved August 2, 2015, from http://downloads01.smarttech.com/media/research/international_research/uk/lancaster_report.pdf

\section{SURVEY MODEL:}

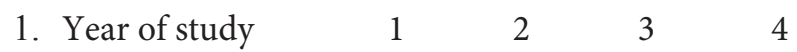

- Do you use Moodle during this academic year? YES / NO

2. Do you have access to the Internet? YES / NO

3. Did you recieve any instructions about how to use Moodle? YES / NO

- Do you consider those instructions necessary? YES / NO

4. How many times per week do you access the Moodle course in contemporary Spanish Language?
A) $0-1$
B) $2-4$
C) $5-6$
D) Everyday
E) More than 5 times a week

Ristić, Miroslava. „E-učenje - nove tehnologije i nastava stranih jezika." Inovacije u nastavi, XIX (3), Učiteljski fakultet: Beograd, 2006: 101-111.

Staker, Heather \& Michael B. Horn. Classifying K-12 Blended Learning. Innosight Institute, 2012. Retrieved July 17, 2015, from http://www.innosightinstitute.org/innosight/wp-content/uploads/2012/05/ Classifying-K-12-blended-learning2.pdf

Thefreedictionary.com “Moodle.” Retrieved July 15, 2015, from http://encyclopedia2.thefreedictionary.com/ Moodle

Virve Siirak. "Moodle E-learning Environment as an Effective Tool in University Education." Journal of Information Technology and Application in Education, Vol. 1 (2), 2012: 94-96. Retrieved June 15, 2015, from www.jitae.org/Download.aspx?ID=5195

Warth-Sontheimer, Claudia. Using Moodle for Language Teaching. A Guide to Moodle Activities for the Language Classroom. University of Tübingen: Tübingen, 2011. Retrieved August 12, 2015, from http:// www.wideminds.eu/moodle/file.php/1/tutorials/ Using_Moodle_for_Language_Teaching_v1.2.pdf

5. How many hours per week do you spend with the Moodle course in Contemporary Spanish Language?
A) 1 hour maximum
B) $1-3 \mathrm{~h}$
C) $3-5 \mathrm{~h}$
D) More than 5 hours a week

6. Do you consider Moodle to be useful for the information necessary about the course Contemporary Spanish Language? YES / NO

7. Which type of material is the most attractive to you? Rank them from 1 to 5 (the most attractive: 1; the least attractive: 5).
$\square$ Text files
$\square$ Audio files
$\square$ Video files
Presentations
$\square$ Graphic files

- Other 
8. Do you think that the lecturer sends you that type of material often enough?
A) Yes.
B) $\mathrm{No}$

9. What type of material does you lecturer upload most frequently? Rank the materials. (the most frequent: 1; the least frequent: 5).

$\square$ Text files

$\square$ Audio files

$\square$ Video files

$\square$ Presentations

$\square$ Graphic files

- Other

10. Did any of these materials influence you?
A) See a movie
B) Listen to a song or a music album
C) Read a book
D) Read an article
E) Take a look at an online gallery of photos
F) Other
G) No, none of the materials from the Moodle influ- enced me in any way

11. If your answer to the previous question is positive, please select the type of material that influenced you most. (choose two answers as maximum)
A) Text files
B) Audio files
C) Video files
D) Presentations
E) Graphic files
F) Other

12. Wich type of content or material do you consider most efficient for learning a language? (choose two answers as maximum)
A) Text files
B) Audio files
C) Video files
D) Presentations
E) Graphic files
F) Other

13. What language competencies can be best developed via Moodle?
A) Oral production
B) Written production
C) listening comprehension
D) Reading comprehension

14. Do you consider some of the language competences to be marginalized on Moodle? YES / NO

If the answer is YES, please state which one:
A) Oral production
B) Written production
C) Listening comprehension
D) Reading comprehension

15. What are the biggest advantages of Moodle? (choose two answers maximum)
A) Constant online presence of the lecturer
B) Possibility of online consultations with other col- leagues
C) Availability of materials at one place
D) Faster access to information
E) Other

16. Moodle's biggest deficiency is

17. Your suggestion: how to improve Moodle course in Contemporary Spanish Language 